Florida International University

FIU Digital Commons

Department of Global and Sociocultural Studies Steven J. Green School of International \& Public

2017

Pensions, Politics, and Soul Train: Anglo-Caribbean Diasporic Encounters with Guantánamo from the War to the Special Period

Andrea Jean Queeley

Follow this and additional works at: https://digitalcommons.fiu.edu/gss_fac

Part of the Social and Behavioral Sciences Commons

This work is brought to you for free and open access by the Steven J. Green School of International \& Public Affairs at FIU Digital Commons. It has been accepted for inclusion in Department of Global and Sociocultural Studies by an authorized administrator of FIU Digital Commons. For more information, please contact dcc@fiu.edu. 


\title{
Pensions, Politics, and Soul Train: Anglo-Caribbean Diasporic Encounters with Guantánamo from the War to the Special Period
}

\author{
by Andrea Queeley
}

[Figure 1 Passage to Cuba and Figure 2 Wedding Photo of Iris]

A member of the late $19^{\text {th }}$ and early $20^{\text {th }}$ century "expanding migratory field" 1 of the Caribbean, Iris ${ }^{2}$ migrated from Jamaica to Banes, Cuba as a child and then from Banes to Guantánamo and Guantánamo to Santiago where she settled down to raise a family. Against the country's move to socialism that followed the 1959 revolution, her husband, a Jamaican carpenter and former Guantánamo Naval Base worker, had returned to Jamaica and died shortly thereafter while she decided to remain in Cuba with her children who were integrating into the revolutionary process. Though still able to manage a faintly marked 'un'-dos-tres' salsa step with her granddaughter, Iris was approaching ninety and had lost sight in one eye when I first met her in the context of conducting ethnographic research on the resurgence of Anglo-Caribbean associations during Cuba's Special Period. As the widow of a Guantánamo Naval Base employee, Iris was owed her husband's pension and early on in our relationship her daughter sought my help in securing this desperately needed income. It was her daughter who told me how the Cubans used to call her mother 'cuca' [ghost/monster] and 'jamaiquina de mierda' [Jamaican shit] and the Americans paid her grandmother a pittance for her labor as a laundress, resenting their dependence on "niggers."

\footnotetext{
${ }^{1}$ This phrase comes from Lara Putnam's The Company They Kept: Migrants and the Politics of Gender in Caribbean Costa Rica, 1870-1960 (2002).

${ }^{2}$ All names have been changed.
} 
Hers was but one of the many lives lived at the intersection of Cuba, the United States, and the African Anglo-Caribbean world. Heeding the call for employment opportunities due to the United States' expansion of the Guantánamo Naval Base during World War II and preference for English-speaking workers, they participated in an internal migration, settling in and around the base. Like the agro-industrial enterprises that Anglo-Caribbean immigrants left behind, the base was racially segregated with people of color being relegated to lower status positions; nevertheless, jobs on the base were prized given the limited options for stable, well-remunerated employment. Racial abjection sat alongside ethnic privilege and economic opportunity as, for some, employment on the base was a source of status and provided a route to realizing the dream of upward mobility. For others, the base was a space of transnational connection and conviviality. With the advent of the 1959 revolution, it became one of the theaters in which the escalating hostilities between the United States and Cuba played out, catching those in the Anglo-Caribbean communities in the crossfire. Now, in the post-Soviet era, connection to and association with the base continues to interject itself into the lives of Cubans of Anglo-Caribbean origin as those with access to pensions enjoy economic advantage in the dual economy. ${ }^{3}$

Centering the narratives of those such as Iris and her family whose encounters with this military complex have spanned well over a half-century, this chapter explores questions of subjectivity, citizenship, and asymmetries of power created by this particular case of militarization. United States military bases and their presence in the Caribbean remain an unexplored space in which the tensions among individuals and communities situated very

\footnotetext{
${ }^{3}$ The dual economy refers to the simultaneous circulation of pesos and U.S. dollars following the 1993 legalization of the dollar.
} 
differently within a given diasporic formation not only unfold, but also are generated. ${ }^{4}$ In this essay, I explore the ways in which this particular Caribbean military encounter has created, been characterized by, and resulted in an ordering/re-ordering of racialized subjectivities.

Connoting the unplanned and unexpected, "encounter" describes not only the hidden transcripts created through militarization but also those moments during ethnographic research in which those transcripts are revealed. Discovering that the base was the site of parties and amorous pursuits, elevated status and racial subjection, conspicuous consumption, clandestine revolutionary activity, and exiles welcomed, painful and perilous, and that this military presence enabled access to Soul Train, the Black American variety show popular in the '70s and ' 80 s, as well as the US dollar in the '90s were all unanticipated moments illuminating the possibilities that militarization enabled and foreclosed. Together these moments reveal a facet of militarization in the region that casts the United States as neither a uniformly benevolent nor a uniformly menacing presence and Caribbean people as neither complicit, complacent, admiring consumers of U.S. hegemony nor agents of resistance to imperial domination. Engagement in transnational practices and the emergence of a diasporic subjectivity have been both alternatives to and facilitated by nation, state, and empire. While in no way dismissing U.S. dominance and practices of physical, psychological, and economic brutality, the voices of Anglo-Caribbean Cubans featured in this chapter indicate that the allegiances and identifications spawned by militarization are far more ambiguous and fluid than most

${ }^{4}$ For a multi-vocal exploration of this theme, see the dialogues that emerged from Deborah Thomas and Tina M. Campt's Diasporic Hegemonies project 2006-2008. 
models of U.S.-Caribbean antagonism or cooperation assume. In this current moment, when diplomatic relations between the U.S. and Cuba have been restored, it is more important than ever to interject the perspectives of those subjects who, through processes of intra-regional migration that have been inextricable from the U.S. economic, political, and military presence, are situated at the intersections of U.S.-Cuban-Caribbean relations.

\section{Guantánamo: Foreground to Background}

July 2015 was an historic month in U.S.-Cuba relations. The previous December President Barack Obama announced that plans were underway to dismantle the 54- year old Palm Curtain constructed between the two countries. ${ }^{5}$ There was a prisoner swap; Cuba was taken off of the list of terrorist-sponsoring states; flags formerly identified as belonging to the enemy were hoisted in D.C. and Havana. But as of this writing, restrictions on travel remain and there is no real talk of giving back Guantánamo, infamous worldwide for its use as a prison camp for enemy combatants in the War on Terror even more than for the questionable circumstances that surrounded its acquisition and maintenance under U.S. jurisdiction. The frontier that became known as the Cactus Curtain in 1961 when Fidel $^{6}$ ordered thousands of cacti to be planted along an 8-mile stretch of the northeastern border, but one move in a series of antagonisms between the U.S. and Cuba, has yet to be torn down - or uprooted. Like a dysfunctional couple that suffered a bitter divorce followed by decades of mutual animosity, complete with brutal

5 The term comes from a 2013 travel article by Malik Ismail entitled "Cuba: Behind the Palm Curtain http://rollingout.com/2013/11/30/cuba-behind-palm-curtain/\#1 accessed July $31^{\text {st }} 2015$.

${ }^{6}$ Fidel refers to both the Fidel Castro, the Cuban president from 1959-2009, and the government apparatus itself. 
fighting over the children caught in the toxic crossfire (sometimes literally...remember Elián?), ${ }^{7}$ they are agreeing to be cordial for the sake of the grandkids. Kissing and making up is highly unlikely, though stranger things than the eventual re-marriage of a couple that has hated and loved each other with equal intensity have happened.

At the time when I was conducting fieldwork in Santiago and Guantánamo in the first decade of the '00s, this reconciliation was somehow both unimaginable and inevitable. My interlocutors were living in the shadow of the Special Period in Peacetime, the euphemism coined by Fidel that referred to the dire economic crisis that followed the collapse of the Soviet Union and tightening of the U.S. embargo. ${ }^{8}$ All Cubans suffered the shock of the sudden disappearance of their principal benefactor/trading partners who had kept their already modest if not austere lifestyles afloat. However, with the massive investment in the tourism industry, the depenalization of the U.S. dollar, and introduction of the dual economy, all reforms that unintentionally favored white Cubans, black Cubans such as those descendants of British Caribbean immigrants who settled in Cuba in the first third of the twentieth century were at a particular disadvantage. ${ }^{9}$ Thus, the Special Period did not end for everyone at the same time. For those who did not have

${ }^{7}$ In 2000, Elián González, a six-year old Cuban boy whose mother had drowned in her attempt to immigrate to the U.S. with him, was at the center of a custody battle between his mother's relatives in Miami, his father in Cuba, and the Cuban and U.S. governments. Ultimately, a federal district court ordered him to be returned to his father and federal agents had to forcibly removed him from the home of his relatives, revealing to the nation the Miami Cuban community's staunch resistance to not only the Cuban government, but also the U.S. government as it did not rule in their favor in this case.

${ }^{8}$ When the Soviet Union collapsed, sending Cuba into an economic tailspin, the U.S. passed the Torricelli Bill in 1992 and The Helms-Burton Act in 1996 to strengthen the embargo against Cuba. The Cuban government understood this as an act of aggression.

${ }^{9}$ See de la Fuente 2001, one of the first analyses of this growing racial disparity. 
access to the industries that were fueling economic growth, life continued to be

"Special.", 10

It was in this context that Melvina, Iris's daughter, asked for my assistance in getting her father's naval base pension on Iris's behalf. She was caring for her mother and the family desperately needed, and were entitled to, this extra monthly income imagined to be collecting dust in a naval base account a 90-minute drive away from Santiago. Though everyone who lived in the house that her Jamaican immigrant father built in the 1940s (this included Melvina, her husband, daughter, and brother) were educated professionals contributing to monthly expenses, their peso salaries and the products on the $\operatorname{libreta}^{11}$ did not provide an adequate supply of basic household and personal consumer goods. ${ }^{12}$ Some former naval base employees and their families were among the fortunate few with access to dollars and Melvina was intent upon being among them.

Established in 1903, the Guantánamo Naval Base is the U.S.'s oldest active overseas military base. It was leased for $\$ 2,000$ a month, which increased to $\$ 4,085$ in 1934 when the Platt Amendment, which gave the U.S. the right to intervene in Cuba's domestic and

\footnotetext{
${ }^{10}$ Fidel declared the Special Period in 1990; however, precisely when the Special Period ended and whether it is over is up for debate. Jorge Pérez López argued that there is no end in sight for Cuba's Special Period. He explained that Cuba's economy was in a free fall until 1994, the first year that it experienced growth, but that this growth was interrupted in 2001 principally due to the global economic slowdown following the September 11th attack and Hurricane Michelle (Pérez López 2002, 2006). See also Benzing 2005; Brundenius 2002; and Mesa-Lago 2001.

${ }^{11}$ Libreta is the ration card containing primarily foodstuffs that the government provided to every Cuban household.

12 In 2004, the CUC or peso convertible, a currency pegged to the U.S. dollar, became the primary currency accepted in what had become known as "dollar" stores. While many, if not most, essential and non-essential goods and services are sold in pesos convertibles, colloquially referred to as cuc, chavito, or divisa, most Cubans are officially paid in Cuban pesos (CUP).
} 
foreign affairs in addition to the land and sea of Guantánamo Bay, was abrogated. As if refusing alimony in public protest and moral indignation, the revolutionary government hasn’t cashed the check since 1959. For the past half century, Guantánamo has been a major staging ground for animosity between the U.S. and Cuban governments.

After initially supporting the rebels who were waging an armed struggle against President Batista, the United States quickly withdrew support of the revolutionary government and the escalation of a hostility that was maintained for over 50 years ensued. Cuba's budding trade relations with the USSR that began with the purchase of 170 thousand tons of sugar in 1959 and the nationalization of sugar centrales and oil refineries, to which the U.S. responded by canceling Cuba's sugar quota, followed by the U.S. imposed trade embargo, the failed Bay of Pigs invasion carried out by CIA-trained Cuban exiles, Fidel's 1961 declaration of the socialist nature of the revolution, and the Cuban Missile Crisis were indicative of island's strategic position in the Cold War. ${ }^{13}$ People who lived and/or worked in Guantánamo, particularly those whose livelihoods were dependent upon the base, were in the middle of this military, ideological, and economic crisis. ${ }^{14}$

One particularly impactful example of this occurred in 1964 when, in retaliation for the U.S. coast guard's detention of 38 Cuban fishermen fishing 70 miles from Key West,

${ }^{13}$ For a succinct chronology of events, see Stubbs 1989: xi-xii.

14 There were also a steady stream of violent and non-violent incidents between Cuban and U.S. personnel across the border. In 1976, after attending the funeral of a Cuban soldier killed by a U.S. soldier in Guantánamo, Raúl Castro announced that no workers on the Base could participate in any revolutionary organizations. This indicates the suspicion towards workers on the Base. 
Cuba cut off the base's water supply. In addition to building a desalination plant on the base, Navy officials, acting on the orders of the Johnson administration, responded by firing the majority of Guantánamo's local employees in a wave of layoffs. ${ }^{15}$ Some 2,000 Cuban employees, many of whom were of Anglo-Caribbean origin, were confronted with the choice of living permanently on the base and cutting all ties to Cuba or living permanently in Cuba and losing their jobs and pensions. Faced with the prospect of being separated indefinitely from their families, initially about 1,500 chose Cuba and 448 workers chose the base. Ultimately, after some negotiation, the U.S. navy allowed 750 people to commute between the base and their homes in Guantánamo and the surrounding towns (Lipman 2009: 183). Their commute onto the base involved physical searches, two buses, two inspections, and a mile-long walk. During this time period, the U.S. turned once again to Cuba's Anglo-Caribbean neighbor to the south for labor as Jamaican (and then Filipino) workers hired through private contractors replaced those Cubans who retired or quit.

The coupling of the dissolution of diplomatic ties with the maintenance of this U.S.controlled space on Cuban soil has resulted in a unique situation for those individuals who, like the stubborn sinews connecting two pieces of butchered flesh, expose the improbability of swift severance, evidencing the depth of interdependency that militarization can create. Since the triumph of the revolution, there have been three categories of Cubans who set foot on the naval base: the commuters, those who chose to exile on the base, and migrants or asylum seekers found on land or sea attempting to

\footnotetext{
${ }^{15}$ In 1959, there were about 3000 base workers who lived in Cuba and worked on the base (Lipman 2009: 146).
} 
cross into U.S.-controlled territory. In 2004, there were 61 Cubans who had exiled on the base remaining, 40 of whom were naturalized U.S. citizens and 34 of whom had been there since the early years of the revolution. The last two of the 750 original commuters retired in 2012. Well into their late 70s, they had labored on the base while living off the base and, after the depenalization of the U.S. dollar, taken responsibility for cashing the pensions of retirees also living in Cuba and delivering the much needed currency to these former coworkers (Rosenberg 2012).

The issue of pensions - who had been able to access them, who had not, and how such access impacted social realities — was the most recent iteration of the persistent presence of the base in the material lives and self-imaginings of Anglo-Caribbean Cubans. Though only a handful of Cubans were recipients of these payments, in my interlocutors' narratives of family and community, association with the resources afforded by base employment was a definitive force in the politics of belonging, community, and cultural citizenship among these black immigrants and their Cuban-born children. This was in part evident in interpersonal tensions stemming from a resentment of the privilege wielded by those with access to pensions in a dual economy in which the local currency was devalued. As one of my interlocutors remarked in response to another jamaicano's suggestion that we take a more expensive form of transportation upon leaving her house: 'That's base money talking." In what follows, I will share some of these narratives of family and community, using them to illustrate how militarization inserted itself into the lives of those on and off of the base, creating fractures as well as fusions. 


\section{"Base Money Talking"}

The base has long represented economic opportunity. With the wartime expansion of the naval base that began aggressively in $1939,{ }^{16}$ thousands of British West Indian immigrants along with their Cuban-born children migrated south from the declining plantation towns of the northeast to Guantánamo in search of better living conditions. ${ }^{17}$ The presence and growth of the naval base boosted the economy of Guantánamo and surrounding towns such as Boquerón and Caimanera, which developed to meet the needs of U.S. servicemen and civilian workers. ${ }^{18}$ In addition to working on the base, British West Indians and their Cuban-born children labored on the railroads, in the brothels and bars, and as laundresses, cooks, and skilled craftsmen. Alberto Jones, a Jamaican Cuban

living in Florida, describes his experience of this internal migration:

My first awareness of WWII may have happened during our evening dinner, in which I heard my grandfather share with us the horrific news coming out of the war zone...At the same time, most people in our community kept talking about the great news coming out of Guantánamo... It may have been either 1943 or 1944, very early in the morning, my mother, my brother and myself, left our modest home in La Guira, Banes and walked the dark trail to the train station and boarded a Gas Car at 5:30AM. Full of hopes, we were elated by the news that had been coming our way describing the better life that awaited us in Guantánamo...When we arrived at the home our grandfather had rented, we were thrilled, delighted with this cinderblock home with Spanish tile floor, electricity, running water and sewer. Albeit

${ }^{16}$ See Lipman (2009: 31-44) for discussion on Naval Base expansion and hiring practices.

${ }^{17}$ Demographers and historians estimate that, between 1898 and 1938, at least 170,000 British West Indians entered Cuba, the majority of them being males from Jamaica. For detailed historical analyses of the migration, see Pérez de la Riva, 1975; Alvarez Estévez, 1988; Wynter 2001; McCleod $2000^{17}$; Giovannetti 2001; Chailloux and Whitney 2005.

18 As with most migrations, the impact of the movement of people and the increased access to resources was not confined to the destination or even departure areas. Incomes earned on the Base fed families living in Santiago and other surrounding cities and it is likely that workers sent money to family members in other parts of Cuba and the Caribbean who could not make the journey themselves. 
poorly equipped, healthcare and educational facilities were available. In less than 24 hours, our living conditions had improved a million percent... Those fortunate to be employed became "different" overnight. Their living standard rose 5,10, 20 or more times compared to their cyclical plantation income, which was for most people reduced to 4 or 5 months and kept them in perennial debt with their employer (Alberto Jones, excerpt from “Guantánamo Remembered” 2001).

At its height in the early 1940s, the base employed 13,000 people and, after the war, had a civilian workforce of approximately 3,500. Though some of the jobs available were for unskilled laborers such as restaurant, commissary and warehouse workers, the skilled tradesmen among the Anglophone Caribbean community powered the expansion of the base. Mechanics, blacksmiths, plumbers, electricians, carpenters, and masons were needed and there were even opportunities for West Indians and their Cuban-born children to work in offices, retail stores selling expensive equipment such as cameras, and as managers of the recreational facilities. Although there were native non-West Indian Cubans working at the base, people of English-speaking Caribbean descent were often preferred to Cubans, a source of discontent amongst non-Anglo-Caribbean Cubans who wanted equal access to the stable employment the base offered (Lipman 2009: 6, 47). ${ }^{19}$

[Figure 3: Photo of BWI working in office on base]

Lester, a physician in his 50s, was one of several interlocutors who noted the distinctions that this access created. He remarked that, "there is no doubt that the Base workers and

\footnotetext{
${ }^{19}$ In part because those born in Cuba after 1940 when the Cuban constitution mandated that all those born on Cuban soil were Cuban citizens and thus categorized as "Cuban" without regard to their Anglo-Caribbean parentage, it is difficult to surmise the precise number of workers who were members of this community. However, out of the 40 participants in this research, 3 had worked on the base and 24 had family members who worked on the base.
} 
their children were better off than others...there wasn't a huge difference, but you could see that the salaries were better, they dressed better, for instance. The morals and behavior and social development of this group was better in the society. People saw us from this point of view so there was a certain difference." 20 Elsewhere, I have argued that employment on the base elevated the status of these black immigrants and their children and reinforced a discourse of respectability (Queeley 2010, 2015). As Elton, a 56-year old Guantanamero and son of a Grenadian carpenter and Jamaican cook who had worked on the base, reasoned, "the antillanos in a certain way were more educado, had more privilege and there were class differences between the jamaicanos and cubanos because the work at the naval base allowed jamaicanos to improve their status in the economic sense. They discriminated against jamaicanos. For example, in the Cuban schools, I was looked upon badly and teased... called 'jamaiquinito' and 'inglesito' because I was well dressed and had nice shoes."21

Melvina was also among those who referred to dress and public appearance as distinguishing Anglo-Caribbean immigrant families from their Cuban and Haitian counterparts. She recalled that her Jamaican carpenter father worked on the base during the week and came home on weekends with food, bags of clothes, shoes and toys for his children and the less fortunate neighbors. He owned a car and the house that he eventually rebuilt with his earnings from the base, the same house that I lived in during my fieldwork. With the money he made on the base, he was able to establish his own

\footnotetext{
${ }^{20}$ Interview with Lester, August $2^{\text {nd }} 2004$, Guantánamo.

${ }^{21}$ Interview with Elton, August $23^{\text {rd }}, 2004$, Santiago.
} 
workshop in Santiago and could afford to take his family on excursions around the island. When explaining that her father always wore a suit and insisted on his children looking neat so that they wouldn't be disrespected, Melvina remarked, “They weren't professionals but they had the feeling of being professional."22

This relative privilege had deep impact on community-building practices and racialized self-making. For example, in order to get onto the base to be assessed for employment, workers needed a pass that could only be given by those already on the base. Thus, hiring occurred through social networks and securing a job on the base was dependent upon community ties. In this way, as well as base employees' role in developing institutional infrastructure off of the base, we can glimpse the repercussions of militarization at the individual and community levels: repercussions firmly remembered as a matter of opportunity that not only facilitated upward mobility in a context of formidable racial and class inequality, but also was shared through immigrant networks. For instance, Isabel's grandfather was a Jamaican blacksmith whose older brother, a mechanic, had brought him onto the base. Ernest, who migrated to Banes from Jamaica as a child, followed his brother to Guantánamo and secured a job on the base as a driver and mechanic. ${ }^{23}$ Winton, who pointed out that all jobs on the base were not created equal, recalled that his father, mother, aunt, and uncle worked on the base in low level positions secured through family connections. ${ }^{24}$ Esperanza, a 69 -year old Guantanamera, recounted how her great

\footnotetext{
${ }^{22}$ Indeed, Cuban historian Graciela Chailloux Lafitta (2005) referred to Anglo-Caribbean immigrants as "a labor aristocracy" (3)

${ }^{23}$ Interview with Lester, August $2^{\text {nd }}, 2004$, Guantánamo.

${ }^{24}$ Interview with Winton, July $11^{\text {th }}, 2004$, Guantánamo.
} 
aunt, who had originally migrated to Banes from Saint Ann's Bay, Jamaica, secured a job on the base working as a domestic and then sent for Esperanza's mother who joined her to also work on the base as a domestic, eventually marrying Esperanza's father, another Jamaican who worked as an office clerk. ${ }^{25}$

Indeed, while the majority of immigrants were males from Jamaica, women figure prominently in the narratives of community as kin, active participants in AngloCaribbean institutions, and as wage earners on or around the base through domestic labor, small businesses (as bakers, seamstresses, laundresses), or as teachers. Notoriously tough disciplinarians, Anglo-Caribbean immigrant women were crucial to this network. For example, while it was Smith's father who got him a job on the base first as a dishwasher, then an orderly when he was 17 years old, between the ages of 4 and 12, Smith had been cared for by English teachers. His Jamaican immigrant mother had become mentally ill and was committed to an asylum where she died, which left his father who was without family in Cuba with little choice but to rely on the women in the community. His father worked as a stable hand and day laborer, giving a portion of his earnings to the Jamaican English teachers caring for Smith, and eventually remarried and secured a job in the nightclub on the base. It was Smith, a vibrant 76 year-old when I began my fieldwork, whose comments about his experience as a base worker illuminated the complexity of the transnational social field the base created. In reminiscing about how much he enjoyed his time on the base, he commented on the presence of African American soldiers and their social relationships with the Cubans, smiling slyly and chuckling as he recalled his

\footnotetext{
${ }^{25}$ Interview with Esperanza, June $8^{\text {th }}, 2005$, Guantánamo.
} 
amorous engagement with a black American woman who lived on the base as the wife of one of the enlisted men. ${ }^{26}$

While Smith remarked that there was racial harmony on the base as long as everyone stayed in their place, Winton was more direct in sharing his experience of racial subjugation. In recounting the racism and disrespect of Navy personnel while he worked as a busboy, he said, "I had a table, they were from the South. They don't like colored people and when they're drunk it's worse. And when the senior server went to get a tip, they say, "get out from here goonie." They curse at you and call you bad names. They didn't like to see [black servers] earning money. There are bosses who don't like people of color anywhere." 27 The naval base, with its racialized occupational stratification, reproduced inequalities and racism even as the social mobility and economic stability that employment on the base enabled for some contributed to the ethnic-based institutions aimed at protecting their members within the broader context of vulnerability and insecurity. It was in this context that discourses of racial uplift and respectability, such as that popularized by the Garvey Movement, flourished.

Figure 4: West Indian Welfare Centre Leadership

\section{Working for the Enemy: Revolutionary Politics and the Dreaded Base Naval}

In the $60 \mathrm{~s} . .$. it was an environment of active participation in the revolution...of contradictory things, shocking things...[on]the border of the naval base...there are

\footnotetext{
${ }^{26}$ Interview with Smith, June $23^{\text {rd }}$, 2004, Santiago.

${ }^{27}$ Interview with Winton, July $11^{\text {th }} 2004$, Guantánamo.
} 
the American guards, and they killed Ramón Peña, and they attacked López ${ }^{28}$... and that family was getting ready to leave for the United States, getting kicked out of the Base so they had no way to live... the church was left empty, the [fraternal] lodges were closed because the people were religious. It was an effervescent environment of contradictions. We lived intense days with great emotions, contradictory emotions. It was like this in the 60s and in the 70s.

--Edward, former president of the West Indian Welfare Centre ${ }^{29}$

The 1959 revolution, with its anti-imperialist nationalist platform, placed those who worked on and around the naval base, viewed by many to be an egregious violation of Cuba's national sovereignty, in the middle of the increasingly antagonistic relationship between the U.S. and Cuba. The triumph of the revolution ushered in an era of radical social change aimed at upending deeply entrenched class relations, relations that had long placed people of color and the working class at a marked and largely inescapable disadvantage. Thus, on the one hand, as black working class people, Anglo-Caribbean Cuban communities ostensibly had much to gain from revolutionary programs providing equal access to education, occupations, and public space. On the other, however, we see that those who were financially dependent on the base and unwilling to weather the revolutionary storms for ideological or economic reasons (or both), viewed the revolution as incompatible with the lives they imagined for themselves and their families. Edward's remarks illustrate the conflicting trajectories of flight from and investment in revolutionary society as well as the base's prominent role in lives lived in revolution.

${ }^{28}$ These men were young Cuban soldiers allegedly shot and killed by U.S. servicemen guarding the base in 1964 and 1966, respectively (see Lipman 2009: 188).

${ }^{29}$ Author interview with Edward on June $5^{\text {th }}, 2005$, Guantánamo. 
From participating in the clandestine movement in the urban areas that supported the revolutionaries who were waging war against the Batista government, to not becoming involved in the politics of a nation that was adopted but still foreign, to choosing exile for economic and political reasons, to taking leadership positions in mass organizations these Anglo-Caribbean Cubans recounted a relationship to the revolutionary process that was fraught with the intensity characteristic of radical social change. In what follows, I provide three vignettes that illustrate this confrontation between militarizations, one inspired by U.S. imperialism and the other by revolutionary nationalism.

\section{Beth}

Beth is a soft-spoken fair-skinned woman with thick glasses and a timidity that is uncharacteristic of most Cubans I have met. She is 67, has a nervous condition and lives with her elderly mother who is the daughter of immigrants from Nevis-St.Kitts. Beth describes hers as a humble family. Her grandfather cut cane and later worked as a dairy farmer and her grandmother was a laundress for the administrator of the central where they lived and then a cook for the railroad once they moved to Guantánamo. Because of her fearful demeanor, her exploits in the clandestine movement came as a surprise to the friend and researcher who introduced us. Indeed, she herself kept repeating that then she hadn't been nervous and afraid before and that the abuses of the government inspired her to action - in particular, the beating and jailing of her father by the Rural Guard. She recounted,

[My father] was Cuban. When someone burned the cane, the rural guard picked him up and put him in jail and mistreated him and beat him... [this] made me against the government...So, a friend of mine was working with the clandestine movement and I started to help her, storing bullets and I carried a lot of messages. I took a bicycle to a place that 
was a central called Cecilia, it's close to here. I got on the bike and put a message in my skirt or in my bloomers and passed the guards [and flirted with them] and passed them by and carried the message.

Beth went on to narrate her ongoing involvement in the clandestine movement once she secured a job on the base, revealing that this U.S. military installation was also the site of pro-revolutionary activities. She explains,

I left Caimanera but on the Base I met a girl who worked with [the rebels] as well and... she went to the frontier and saw the MauMau ${ }^{30}$ she had to see and gave him the message and he gave her July $26^{\text {th }}$ bonds. ${ }^{31}$ Another friend of mine A--, a jamaiquina also, sold the bonds, and to the Americans also because at that time the Americans loved Fidel. They lived in love with him and we sold the July 26th bonds... We [also] came from the Base and carried cigars and food to the MauMau in Cayo Torro... ${ }^{32}$

Beth's testimony provides a glimpse of what occurred inside of the grooves carved out by people who were 'working for the enemy' and found themselves between the force of revolutionary activity and that of a repressive dictatorship that was supported by the U.S. government, though clearly not unilaterally by its representatives. ${ }^{33}$

With the victory of the rebel forces, jamaicanos's preoccupations as articulated by interviewees who remained in Cuba were linked to the uncertainty about their economic and material futures. For instance, Edward's St. Kittsian grandfather had retired from the Base and, at the time of the revolution, was dependent upon a pension that, with the new regulations in Cuba pertaining to the U.S. dollar, he would no longer be able to draw upon. Though his children were more than willing to support him, the prospect of losing

\footnotetext{
${ }^{30}$ Some participants used this name to refer to the rebels. It is a reference to the Kikuyu anticolonial fighters of Kenya.

${ }^{31}$ The rebels and those who supported them sold July $26^{\text {th }}$ bonds as a means of raising funds for the anti-Batista rebellion.

${ }^{32}$ Interview with Beth, June $29^{\text {th }} 2005$, Guantánamo.

${ }^{33}$ Batista, in part as a result of his commitment to root out communism through the Bureau to Repress Communist Activities, was supported by the U.S. government.
} 
financial independence motivated him to leave his family and migrate to Jamaica with his Jamaican-born companion whom he met in Cuba after his Montserratian wife died.

The erosion of their institutional infrastructure no doubt encouraged the departure of many community members, particularly those original immigrants who were more active in the organizations founded by their own cohort. Their livelihoods had always been dependent upon North Americans, and they were less amenable to becoming further incorporated into Cuban society. Of the participants in this study, eleven had immediate family members who left Cuba during the first 15 years of the Revolution either through migrating or exiling on the Base. One participant, Winton, actually attempted to leave through swimming onto the Base but was caught and jailed for three years. Another, Pamela, applied to migrate to the United States and, once the municipal authorities in Guantánamo discovered this, she was denied the opportunity to study, and instead made to do agricultural work with the rationale that the revolution is not going to invest resources in people who intend to abandon the country. Thus, in an environment where government propaganda cast Cubans who left as traitors and counterrevolutionaries, everyday and official social actors met the declaration of intent to do so with ostracism and punishment.

\section{Leonarda}

Leonarda, age fifty-five at the time of my fieldwork, is the daughter of a Jamaican immigrant and the Cuban-born son of Jamaican immigrants. Her parents migrated from Banes to Caimanera in order to work on the Base. Her father worked in a nightclub and 
her mother was a housewife and, in more difficult times, worked as a laundress. They had eight children; her father died at a fairly young age and her mother remarried another Jamaican descendant who had a job on the Base. Her mother left the country in 1970 and now lives in California. The following excerpt from an interview with Leonarda illustrates the social terrain that some people of English-speaking Caribbean descent had to navigate during the early period of the Revolution as well as the dispersion of family through further migration:

There were different bars [in Caimanera], one was a store by day and by night, they put out a vitrola and there was music and sailors came. There were problems ... they thought that they were the owners of the street and everything...these are things I heard [from adults]. I was young, nine when the revolution triumphed. The first school I went to was the English school with Ms. Odein...she was de madre [really difficult or hard]...I was in a private school with her so that I could be prepared to do well in the Spanish public school...It was important for us to be able to communicate [in English] because [my mother] insisted on one thing. My mother was accustomed to when she called us, we answered in English and if everything wasn't in English, she hit you...but also the English language at that time was important and later [after the triumph of the revolution] it was a little...well, people said 'English, for what? English, for what?'... When my mother called me, I preferred to get hit than to answer in English. When I was inside the house I answered in English, but outside I [didn't speak English]... and when I went to the public school and the teacher would call on me, I accidentally answered 'Yes teacher' [said in English] ... and this embarrassed me...[there was] a little rejection, so when [jamaicanos] were together one felt a little shy, prohibited in speaking...

[My mother] looked at [the revolution] and she said, 'well, I don't like the system'... because she saw that it was communism and she didn't like this and she didn't want to stay. The older ones stayed and the little ones left with my mother. When [she] left, I finished my nursing training. Before this, I had some problems studying because to study, I had to do mathematics and Spanish exams and they always failed my oral exam. I had to present myself in various exams in order to qualify for the major and it was always the same, always the same...I think that everything that they asked me I answered correctly and tell me what's this about? They asked me if I had family outside of the country and I say 'yes'. They asked 'who' and I said 'my mother and some of my brothers and sisters'. My stepfather worked on the Base, he was still alive. And they asked if I liked parties and I said 'yes'. Now, I wanted a career where I knew that I had to work and if there's a party, I know I have to work...but for this they failed me. But eventually 
they accepted me because they knew me from before as I had gone to various exams [and hadn't given up]. With me, what happened was that they thought 'no, no, no, they're not going to educate someone to be a nurse so that she can leave my country'...Later I understood and if they [didn't give me a chance] I'd have to leave the country because what else could I do here? If I couldn't study, I couldn't do anything. So, I spoke with them so that they would understand and from there I studied and graduated in general nursing and pediatric nursing. ${ }^{34}$

Due to the threat to national security posed by the United States, primarily in the form of militant Cuban exiles determined to wrest the country from the revolutionary government, association with the U.S. was policed. My Anglo-Caribbean interlocutors recalled this as a time when connections to elsewhere, and especially to the base, which was the 'elsewhere' within, placed one's loyalty to Cuba in question. As such, those committed to integrating into the revolutionary process had to clearly demonstrate that they chose Cuba over even the most intimate connections. The following passage shared by Edward, the grandson of eastern Caribbean immigrants and base workers, narrates his family's experience of heart-wrenching division:

My uncle R., he integrated [into the revolution] and had worked as a fireman but then he went to work at the Ministry of the Interior and he kept moving up and moving up and he ended as a senior in the Ministry of the Interior...He studied and got a degree in political science and this was a way he bettered himself and he integrated into the Party and was a combatant. So, what happens, in my family, people who had this kind of integration into these organizations, in the antillana family, a big division was created [and also] there was a rejection... Certain relationships, including with your own family who weren't like this [revolutionary] were prohibited. For example, my Uncle R., after entering the Ministry of the Interior, he separated from our family. Why? Because my father worked in the naval base, my Uncle B. worked in the naval base, my Uncle T. worked in the naval base, my aunt was religious, so he separated from the family. He was over there and the family over here.

The first time my father came to Cuba in 1980, after he exiled on the Base in 1972, I remember walking with him on Pedro Pérez Street to visit a friend of his who lives north of there and we were walking, near Curado, and my Uncle R. was on the sidewalk at a cafeteria at the time when he had a position with the Ministry of the Interior. We came on the sidewalk and when my Uncle R. saw that it was us coming, we were about 50 meters

\footnotetext{
${ }^{34}$ Interview with Leonarda, June $29^{\text {th }}, 2005$, Guantánamo.
} 
away, he left and entered into the Ministry because it was prohibited for him to have contact with people abroad. And I remember that my father, when this happened, my father quickly crossed the street as he had recognized [my uncle] immediately though they hadn't seen each other for years...I said 'look, that was my uncle R.' and he said 'yes, didn't you see what he did?' and I said 'yes' and he said to me 'what a thing, my God, let's go, let's go cross the street'. And we crossed another street and he said, and I remember he made this expression 'why, God, why does it have to be like this...let's cross because I didn't come here to cause problems for anyone'... ${ }^{35}$

This severance of ties to the U.S. and the world beyond the Palm Curtain was by no means absolute. There were narrow gaps in that curtain as a result not only of the retention of commuters between "Cuba" and the base, but also of the media that could not be confined to the base. As it turns out, people in Guantánamo were able to pick up the satellite signal from the base and access U.S. television programs made available to military personnel. Remembering the music of the 60s and early 70s and its global distribution, Lester, 55, reflected, "we had the privilege of being able to watch the channel from the base so we saw musical groups and watched Soul Train every week. The youth at this time wanted to leave [English class at the British West Indian Welfare Centre] to watch this show. There was also Soul of the City but the most memorable was Soul Train and this had a lot of impact in Guantánamo from the point of view of the styles and dances...this was a privilege because we were the first to get access to black American culture." $" 36$

This unique circumstance created by proximity to the base came up again in a casual conversation with Edward when we were discussing our favorite musicians. In speaking about his love of Luther Vandross and other black American R\&B singers, he recounted

\footnotetext{
${ }^{35}$ Interview with Edward, June $28^{\text {th }}$ 2005, Guantánamo.

${ }^{36}$ Interview with Lester, August $2^{\text {nd }}, 2004$, Guantánamo.
} 
how, every Saturday morning during the 1970s and into the 1980s, he and other people in his neighborhood would crowd around a television and watch Soul Train. ${ }^{37}$ For

Guantanameros, the proximity of the U.S. Naval Base led to the unexpected movement of information and cultural material that was by and large forbidden for mass consumption. ${ }^{38}$ Unlike other Cubans, residents of the city were able to take full advantage of this lapse in media control and listened to the music and practiced the dance moves of black America.

Elsewhere, I have discussed my Soul Train revelation as a moment of what Hintzen and Rahier (2010) refer to as the mutual recognition out of which diaspora is produced in the context of the misrecognition and distortion enacted by the racist lens (Queeley 2015). When we understand diaspora as a conceptual framework through which to look at various articulations of displacement and belonging, one that decenters the nation-state as the basis of connection and relies on the imagining of a shared past and/or a shared experience of degradation, the discovery that people in Guantánamo had access to Soul Train in the 1970s and 80s illuminates the processes and politics around the creation of a diaspora space that exceeds the mere presence of those who come from elsewhere. ${ }^{39}$ This particular case of militarization highlights the kinds of entanglements and asymmetries of power that are often ignored in understandings of diaspora. Access to employment generated by the presence of the U.S. base allowed for a connection to the larger world of black popular culture. This connection added yet another dimension to the

\footnotetext{
${ }^{37}$ Field note, August $29^{\text {th }} 2005$.

38 The revolution's nationalistic program involved a black out of all foreign cultural material (with the exception of that coming from the socialist bloc).

${ }^{39}$ See Avtar Brah (1996)
} 
transnationality that the base engendered, invigorating Anglo-Caribbean Cubans'selfunderstandings that extend beyond Cubanness to encompass U.S. and pan-AngloCaribbean cultures.

\section{A Question of Security}

In 2012, about 8500 Americans lived on the Guantánamo Naval Base. Three thousand of these were service members and 1000 were family to service members, 500 of them children. "We're a small American town...we think we're a throwback to the '50s," said base commander Navy Captain Les McCoy when interviewed in 2012 for U.S. Department of Defense news article. ${ }^{40}$ That same year, I attended the memorial service of Edward's father who had exiled on the base and been the golf course manager for decades before retiring in the Dominican Republic. In spite of his declaration that, based on his interactions with white American military personnel, he would never live in the United States, he eventually migrated to Florida, which became his final resting place. During the repast, I sat next to a young man who, after I shared with him how I knew the

${ }^{40}$ See "Guantanamo Bay Base Has a Storied Past" by Kathleen T. Rhem, American Forces Press Service, August $24^{\text {th }} 2004$. 
family and explained my research, told me that he had grown up on the base as the child of Jamaican base workers. He moved to Florida to attend college and thus had essentially spent his formative years in this militarized space. When I asked him what it was like growing up on the base, he recalled a pleasant childhood complete with fast food chains, basketball courts, and cable television. He made no mention of the racial politics that would have accompanied a small American town in the 1950s and to which Edward's father reacted. Among the questions that this raises is the extent to which, like the homeland in certain articulations of diaspora, this infamous U.S. military installation is for some an idyllic, and perhaps utopic, space.

By way of conclusion and analogy to another Caribbean space with a troubled history of militarization, I feel compelled to share a moment that I experienced in a Miami classroom geographically close to but experientially distant from Guantánamo. Shortly after the devastating 2010 earthquake in Haiti, former dictator "Baby Doc" Duvalier returned to Haiti with the rumored intention to take office. One of my Haitian American students remarked that what Haiti needed in order to extricate itself from the crisis was a strong leader like Duvalier. Somehow, the heinous crimes, violent in both economic and corporeal terms, committed by the regime seemed excusable when weighed against the alleged order and stability that authoritarianism brought to the country. In the absence of more just alternatives, there are those who elect for the security that militarization provides, whether part and parcel of the U.S. presence in the region or the modus operandi of national governments. Thus, I believe that a commitment to demilitarization must involve working to create those just alternatives. 


\section{Bibliography}

Andrews, George Reid. Black Workers in the Export Years: Latin America, 1880-1930. International Labor and Working-Class History 51 (1997): 1-23.

Ayala, César J. American Sugar Kingdom: The Plantation Economy of the Spanish Caribbean, 1898-1934. Chapel Hill: University of North Carolina Press, 1999.

Azicri, Max. Cuba Today and Tomorrow: Reinventing Socialism. Gainesville: University Press of Florida, 2000.

Benzing, Cynthia. Cuba--Is the Special Period Really Over? International Advances in Economic Research 11 no.1 (2005): 69-82.

Blue, Sarah. The Erosion of Racial Equality in the Context of Cuba's Dual Economy. Latin American Politics and Society 49 no. 3 (2007): 35-68.

Blum, Denise. Socialist Consciousness Raising and Cuba's School to the Countryside Program. Anthropology and Education Quarterly 39 no. 2 (2008): 141-160.

----2011. Cuban Youth and Revolutionary Values: Educating the New Socialist Citizen. Austin: University of Texas Press.

Bourgois, Phillipe. Ethnicity At Work: Divided Labor on a Central American Banana Plantation. Baltimore: John Hopkins University Press, 1989.

Brah, Avtar. Cartographies of Diaspora: Contesting Identities. London: Routledge, 1996.

Brundenius, Claes. Whither the Cuban economy after recovery?: The reform process, upgrading strategies and the question of transition. Journal of Latin American Studies 34 (2002): 365-395.

Bryce-Laporte, Roy S. Crisis, Contraculture, and Religion Among West Indians in the Panama Canal Zone. In Norman Whitten and Arlene Torres (eds) Blacks and Blackness in Latin America and the Caribbean Vol. I Central America and the Northern South American Lowlands. Bloomington: University of Indiana Press, 1998. 
Cabezas, Amelia. Between Love and Money: Sex, Tourism, and Citizenship in Cuba and the Dominican Republic. Signs: Journal of Women in Society and Culture 29 no. 4(2004): 987-1015.

Campt, Tina and Deborah Thomas. "Gendering Diaspora: Transnational Feminisms, Diaspora, and Its Hegemonies" Feminist Review 90 (2008): 1-8.

Carr, Barry. 'Omnipotent and omnipresent?' Labor shortages, Worker Mobility, and Employer Control in the Cuban Sugar Industry, 1910-1934. In Aviva Chomsky and Antonio Lauria-Santiago (eds) Identity and Struggle at the Margins of the Nation-state: the Laboring Peoples of Central America and the Hispanic Caribbean, 260-291. Durham, NC: Duke University Press, 1998a.

----Identity, Class and Nation: Black Immigrant Workers, Cuban Communism, and the Sugar Insurgency, 1925-1934. The Hispanic American Historical Review 78 no. 1(1998b):83-116.

Charlton, Audrey. "Cat Born in Oven is Not Bread:" Jamaican and Barbadian Immigrants in Cuba Between 1900 and 1959. Dissertation, Columbia University, 2005.

Chailloux, Graciela L. "Introducción: ¿De Dónde Son los Cubanos? In Graciela Chailloux Lafitte (ed), De Dónde Son los Cubanos, 1-4. Editorial de Ciencias Sociales: La Habana, 2005.

Chailloux, Graciela and Robert Whitney. "British Subjects y Pichones en Cuba" In Graciela Chailloux Lafitte (ed), De Dónde Son los Cubanos, 53-91. Editorial de Ciencias Sociales: La Habana, 2005.

Chomsky, Aviva. West Indian Workers and the United Fruit Company in Costa Rica, 1870-1940. Baton Rouge: Louisiana State University Press.

-Conniff, Michael. 1985. Black Labor on a White Canal: Panama, 1904-1981. Pittsburgh: University of Pittsburgh Press, 1996.

De la Fuente, Alejandro. The resurgence of racism in Cuba. NACLA Report on the Americas, 34 no. 6(2001): 29-34.

Echeverri-Gent, Elisvinda. Forgotten Workers: British West Indians and the Early Days of the Banana Industry in Costa Rica and Honduras. Journal of Latin American Studies 24 (1992): 275-308.

Eckstein, Susan. Dollarization and Its Discontents: Remittances and the Remaking of Cuba in the Post-Soviet Era. Comparative Politics 36 no. 3(2004): 313-330.

Giovannetti, Jorge L. Black British Subjects in Cuba: Race, Ethnicity, Nation, and Identity in the Migratory Experience, 1898-1938. Dissertation, University of North London, 2001. 
----"The Elusive Organization of "Identity": Race, Religion, and Empire Among Caribbean Migrants in Cuba." Small Axe: A Caribbean Journal of Criticism 10 no.1(2006a): 1-27.

----"Black British Caribbean Migrants in Cuba: Resistance, Opposition, and Strategic Identity in the Early Twentieth Century" In Annette Insally, Mark Clifford and Sean Sheriff (eds) Regional Footprints: The Travels and Travails of Early Caribbean Migrants, 103-120. Mona: Latin American and Caribbean Centre, 2006b.

Hintzen Percy and Jean Rahier. "Introduction: Theorizing the African Diaspora: Metaphor, Miscognition, and Self-Recognition" In Jean Muteba Rahier, Percy Hintzen and Felipe Smith (eds) Global Circuits of Blackness: Interrogating the African Diaspora, x-xxvi. Urbana-Champaign: The University of Illinois Press, 2010.

Jones, A. Guantánamo Remembered [online]. Available from: afrocubaweb.com/ albertojones/albertojones3.htm (accessed May 2001).

Lipman, Jana. Guantánamo: A Working Class History Between Empire and Revolution. Berkeley: University of California Press, 2009.

McLeod, Marc C. Undesirable Aliens: Race, Ethnicity, and Nationalism in the Comparison of Haitian and British West Indian Immigrant Workers in Cuba, 1912-1939. Journal of Social History. Spring (1998): 599-623.

----Undesirable Aliens: Haitian and British West Indian Immigrant Workers in Cuba, 1898-1940. Ph.D., University of Texas, 2000.

Mesa-Lago, Carmelo. The Cuban Economy in 1999-2001: Evaluation of Performance and Debate on the Future. Cuba in Transition--Association for the Study of the Cuban Economy 11(2001): 1-17.

Nassy Brown, Jacqueline. Black Liverpool, Black America, and the Gendering of Diasporic Space. Cultural Anthropology 13 no.3(1998): 291-325.

----Dropping Anchor, Setting Sail: Geographies of Race in Black Liverpool. Princeton: Princeton University Press, 2006.

Newton, Velma. The Silver Men: West Indian Labour Migration to Panama 1850-1914. Kingston: The Sir Authur Lewis Institute of Social and Economic Studies, 1984.

Petras, E.M. Jamaican Labor Migration: White Capital and Black Labor, 1850-1930. Boulder, CO: Westview Press, 1988.

Putnam, Laura. The company they kept: migrants and the politics of gender in Caribbean Costa Rica, 1870-1960. Chapel Hill: University of North Carolina Press, 2002.

Stubbs, Jean. Cuba: The Test of Time. London: Latin American Bureau (Research and Action) Limited, 1989. 
Thomas, Deborah and Tina M. Campt "Diasporic Hegemonies: Slavery, Memory, and Genealogies of Diaspora". Transforming Anthropology 14 no. 2(2006):163-172.

Thomas, Deborah and Tina M. Campt, Maureen Mahon and Lena Sawyer. "Diasporic Hegemonies: Popular Culture and Transnational Blackness 15 no.1 (2007): 50-62.

Wynter, Cadence A. Jamaican Labor Migration to Cuba, 1885-1930. Ph.D., University of Illinois, 2001.

Zimbalist, Andrew. Reforming Cuba's Economic System from Within. In Jorge F. PérezLópez (ed) Cuba at a Crossroads: Politics and Economics after the Fourth Party Congress, 220-237. Gainesville: University Press of Florida, 1994a.

----Treading Water: Cuba's Economic and Political Crisis. In Donald E. Schulz (ed) Cuba and the Future, 7-22. Westport and London: Greenwood Press, 1994b. 